Ks. Kazimierz Talarek ${ }^{*}$

Nagoszyn

\title{
PRZYGOTOWANIE I PRZEBIEG WIZYTY \\ JANA PAWLA II W TARNOWIE W DNIACH \\ OD 9 DO 10 CZERWCA 1987 ROKU W ŚWIETLE DOKUMENTÓW SPRAWY OBIEKTOWEJ „PIELGRZYM"1
}

Stowa klucze:

Służba Bezpieczeństwa, bł. Jan Paweł II, abp Jerzy Ablewicz, plac Katedralny, Tarnów

Treść:

I. Założenie sprawy obiektowej

II. Powołanie sztabu kierującego zabezpieczeniem wizyty papieskiej w Tarnowie

III. Operacja „Posesja”

IV. Dalsze przygotowania

V. Rozmowy ze stroną kościelną

VI. Zabezpieczenia i kryptonimy

VII. Wniosek o zakończenie sprawy obiektowej

Okazją do trzeciej wizyty Jana Pawła II w Polsce stał się krajowy Kongres Eucharystyczny, ale dziś niewatpliwie wiadomo, że kolejna wizyta papieża w Polsce była zaplanowanym etapem w procesie „rozmiękczania”

\footnotetext{
${ }^{*}$ Ks. Kazimierz Talarek, dr hab. nauk humanistycznych z zakresu historii, proboszcz w Nagoszynie.

${ }^{1}$ Sprawa obiektowa to jedna $\mathrm{z}$ form pracy operacyjnej prowadzonej w celu zapewnienia stałego dopływu informacji o instytucjach, środowiskach i wydarzeniach istotnych z punktu widzenia działań operacyjnych, a także zapobiegania działalności antysystemowej lub kontaktom z opozycją, próbom penetracji obiektów przez obce służby, szkodnictwu i sabotażowi gospodarczemu, łamaniu tajemnicy państwowej i służbowej, niedostatecznemu zabezpieczeniu obiektów (por. F. Musiał, Podręcznik bezpieki. Teoria pracy operacyjnej Stużby Bezpieczeństwa $w$ świetle wydawnictw resortowych Ministerstwa Spraw Wewnętrznych PRL [1970-1989], Kraków 2007, s. 346).
} 
systemu totalitarnego. Władza komunistyczna w Polsce chyliła się ku upadkowi, co stało się faktem 2 lata później ${ }^{2}$. Przy narastaniu opozycji antykomunistycznej w Polsce, gdy Kościół udzielał schronienia ludziom polskiej kultury i udostępniał im budynki sakralne do wystąpień, papież Jan Paweł II podjął decyzję o przyjeździe do Polski. Droga watykańskiego pielgrzyma objęła: Warszawę, Lublin, Tarnów, Kraków, Szczecin, Gdynię, Gdańsk, Częstochowę, Łódź i Warszawę. W czasie pielgrzymki w Tarnowie dokonał beatyfikacji Karoliny Kózki, zamordowanej 18 listopada 1916 roku przez rosyjskiego żołdaka, natomiast w Warszawie bpa Michała Kozala, męczennika z Dachau. Homilie i przemówienia papieskie mówiły o dojrzałym społeczeństwie, rodzinie katolickiej, prawie do życia. Była to ostatnia pielgrzymka papieża w Polsce komunistycznej ${ }^{3}$.

Prezentowany artykuł ukazuje przygotowanie do wizyty papieża Jana Pawła II w Tarnowie w świetle dokumentów zawartych w teczce sprawy obiektowej o kryptonimie „Pielgrzym”, którą udało się odnaleźć w Archiwum IPN w Wieliczce.

\section{ZAŁOŻENIE SPRAWY OBIEKTOWEJ}

Plan operacji „Zorza II”, którego celem była odpowiednia „ochrona operacyjna" trzeciej pielgrzymki Jana Pawła II do Polski, powstał w MSW już na przełomie 1986 i 1987 roku. Kierownikiem sztabu operacji został gen. Zbigniew Pudysz. Odbiciem centralnej operacji „Zorza II” były jej regionalne mutacje tworzone przez wojewódzkie urzędy spraw wewnętrznych ${ }^{4}$. W MSW przyjęto założenia operacji, które przygotował Zarząd PolitycznoWychowawczy resortu. Departament III w związku z przygotowaniami do wizyty papieża planował ,zapewnienie pełnej kontroli operacyjnej ustalonych nielegalnie struktur, grup i osób znanych z wrogich postaw politycznych" ". Działaniom związanym z zabezpieczeniem pobytu Jana Pawła II na terenie województwa tarnowskiego został nadany kryptonim „Zorza II”,

8 stycznia 1987 roku zastępca naczelnika Wydziału IV WUSW w Tarnowie kpt. A. Kwaśniewski skierował do zastępcy komendanta WUSW w Tarnowie płk J. Schillera wniosek o wszczęcie sprawy obiektowej o kryptonimie „Pielgrzym”. We wniosku napisano: „W czerwcu 1987 r. planowana jest wizyta papieża Jana Pawła II oraz uroczystości beatyfikacyjne Karoliny

\footnotetext{
${ }^{2}$ Śladami Jana Pawła II. 25 lat pontyfikatu, red. M. Latasiewicz, Kraków 2003, bez paginacji.

${ }^{3}$ B. Kumor, Historia Kościoła, t. VIII, Lublin 1995, s. 532-533; M. Różański, II Kongres Eucharystyczny w Polsce - rok 1987, Łódź 2007, s. 99-100.

${ }^{4}$ Operacja „Zorza II”. Stużba Bezpieczeństwa i Komitet Wojewódzki PZPR wobec wizyty Jana Pawła II w Trójmieście (czerwiec 1987), red. S. Cenckiewicz, M. Kruk, Warszawa - Gdańsk 2008, (wstęp) s. XIV.

${ }^{5}$ A. Dudek, R. Gryz, Komuniści i Kościót w Polsce (1945-1989), Kraków 2006, s. 429.

${ }^{6}$ AIPN Kr 034/30, k. 119, Decyzja nr 04/87 Szefa Wojewódzkiego Urzędu Spraw Wewnętrznych w Tarnowie z dnia 15 I $1987 \mathrm{r}$.
} 
Kózki w Tarnowie. W związku z powyższym, zgodnie z Zarządzeniem nr 003/72 z dnia 4 III 1972 r. Dyr.[ektora] Dep.[artamentu] IV MSW w sprawie obiektów i zagadnień, na które winny być prowadzone sprawy obiektowe i materiały operacyjne, zachodzi potrzeba założenia sprawy obiektowej na w/wym.[ienione] uroczystości. Pozwoli to na organizację pracy operacyjnej przy rozpoznaniu, zabezpieczeniu i dokumentowaniu przebiegu wszelkich uroczystości związanych z pobytem papieża i beatyfikacją". Wniosek został zatwierdzony ${ }^{7}$.

\section{POWOŁANIE SZTABU KIERUJACEGO ZABEZPIECZENIEM WIZYTY PAPIESKIEJ W TARNOWIE}

Szef WUSW w Tarnowie płk mgr Edward Kubrak 15 stycznia 1987 roku decyzją nr 04/57 powołał przy Wojewódzkim Urzędzie Spraw Wewnętrznych w Tarnowie sztab mający na celu właściwe określenie i wykonanie zadań związanych z zabezpieczeniem wizyty Jana Pawła II w Tarnowie w dniach od 9 do 10 czerwca 1987 roku. W skład sztabu weszli:

1. Kierownik sztabu: płk J. Schiller, zastępca szefa WUSW ds. Bezpieczeństwa.

2. Zastępcy kierownika sztabu: płk E. Ceglarski, zastępca szefa WUSW ds. MO; płk S. Cochara zastępca szefa WUSW ds. AG.

3. Członkowie sztabu: ppłk T. Boczar, naczelnik Wydziału IV SB; mjr Z. Wójcik, naczelnik WZO; mjr Wł. Golik, naczelnik Wydziału GMT; kpt. J. Mach zastępca dowódcy ZOMO; ppłk A. Turotszy Naczelnik Wydziału II SB; mjr R. Waśkowicz, naczelnik Wydziału III SB; mjr S. Boruch Naczelnik Wydziału V SB; kpt. J. Kolenda Naczelnik Wydziału Łączności; ppłk J. Bryk, naczelnik Wydziału Śledczego; kpt. R. Pękala, naczelnik Wydziału Ruchu Drogowego; kpt. A. Sztorc, naczelnik Wydziału PolitycznoWychowawczego.

Obowiązkiem członków sztabu było organizowanie działań operacyjnorozpoznawczych związanych z wizytą Papieża na terenie Tarnowa. Do ich zadań należało udzielanie pomocy służbom bezpośrednio odpowiedzialnym za bezpieczeństwo Papieża, podejmowanie działań porządkowych oraz przeciwdziałanie ,wrogim zamierzeniom związanym $\mathrm{z}$ pobytem papieża". Ponadto zostały utworzone zespoły robocze:

1. Zespół do Działań Operacyjno-Politycznych w składzie: kierownik zespołu - ppłk T. Boczar, naczelnik Wydziału IV SB; zastępcy - kpt. A. Kwaśniewski, zastępca naczelnika Wydziału IV SB; mjr R. Guzicki, zastępca naczelnika Wydziału III SB.

2. Zespół Ochrony Porządku Publicznego: kierownik - płk E. Ceglarski, zastępca szefa WUSW ds. MO; członkowie - ppłk M. Sarkowicz, naczelnik Wydziału Prewencji; ppłk F. Hain, szef RUSW w Tarnowie; kpt. k. 3 .

${ }^{7}$ AIPN Kr 034/30, Wniosek o wszczęcie sprawy obiektowej o kryptonimie „Pielgrzym”, 
T. Ożga, zastępca szefa RUSW w Tarnowie; kpt. S. Dziedzic, inspektor Wydziału Prewencji.

3. Zespół Zabezpieczenia Materiałowo-Technicznego: kierownik - mjr Wł. Golik, naczelnik Wydziału GMT; członkowie - kpt. F. Florek, zastępca naczelnika Wydziału GMT; kpt. S. Duch, naczelnik Wydziału Zdrowia.

4. Zespół Polityczno-Wychowawczy: kierownik zespołu - kpt. T. Sztorc, naczelnik Wydziału Polityczno-Wychowawczego; członkowie - kpt. T. Ożga, zastępca szefa RUSW w Tarnowie ds. polityczno-wychowawczych; kpt. J. Warzecha, zastępca naczelnika Wydziału Kadr; kpt. Z. Obrzut, starszy inspektor Wydziału Polityczno-Wychowawczego.

5. Zespół Informacyjno-Sprawozdawczy: kierownik - naczelnik Wydziału Ogólnego; członkowie - kpt. M. Chwistek, starszy inspektor SB; kpt. W. Jagowdzik, starszy inspektor Wydziału IV SB; por. W. Malinowski, starszy inspektor Wydziału III SB.

Decyzje kierownika sztabu WUSW w Tarnowie w zakresie zabezpieczenia wizyty papieskiej były wiążące dla kierowników jednostek organizacyjnych garnizonu tarnowskiego. W razie zagrożenia bezpieczeństwa lub zakłócenia porządku publicznego mogły być użyte oddziały lub pododdziały $\mathrm{MO}^{8}$.

W późniejszym czasie skład tego sztabu uległ nieznacznej zmianie. Decyzją szefa WUSW z 20 lutego 1987 roku zmianie uległ skład osobowy Zespołu Ochrony Porządku Publicznego i wyglądał następująco: kierownik - płk E. Ceglarski; członkowie - ppłk M. Sarkowicz; ppłk F. Hain; mjr K. Znamirowski; mjr J. Pogonowski, naczelnik Wydziału Kryminalistyki WUSW; kpt. A. Huk, naczelnik Wydziału Kryminalnego WUSW; kpt. R. Pękala, naczelnik Wydziału Ruchu Drogowego WUSW; kpt T. Ożga, zastępca szefa RUSW w Tarnowie ds. polityczno-wychowawczych; kpt. J. Mach, zastępca dowódcy ZOMO.

Powołano wtedy także kilka innych zespołów. Były to:

1. Zespół Koncepcyjno-Sztabowy w składzie: kierownik - mjr K. Znamierowski; członkowie - kierownicy poszczególnych zespołów oraz kpt. A. Huk, kpt. T. Ożga, kpt. J. Mach, por. T. Koraś, por. T. Ciuruś. Temu zespołowi polecono zadanie opracowania koncepcji zabezpieczenia, przygotowanie stosownych dokumentów graficznych i opisowych, prognozowanie rozwoju sytuacji, kalkulacje sił i środków, a w szczególności opracowanie harmonogramu przedsięwzięć organizacyjno-wykonawczych, opracowanie planu rozśrodkowania ludności, planu zabezpieczenia głównej uroczystości itp.

2. Zespół Organizacji i Działania Stanowisk Kierowania i Stanowisk Dowodzenia w składzie: kierownik - mjr J. Pogonowski; członkowie - por. R. Margosiak, kpt J. Lis, st. chor. W. Bełzowski, kpt. rez. S. Dynak. Zadaniem tego zespołu było m.in. przygotowanie obsady personalnej stanowisk kierowania, stanowisk dowodzenia i opracowanie dokumentów tajnego dowodzenia.

${ }^{8}$ AIPN Kr 034/30, k. 117-119, Decyzja nr 04/87 Szefa Wojewódzkiego Urzędu Spraw Wewnętrznych w Tarnowie z dnia 15 I $1987 \mathrm{r}$. 
3. Zespół ds. Organizacji Ruchu: kierownik - kpt. R. Pękala; członkowie - kpt. Wł. Warzecha, kpt. J. Uryga, kpt. A. Gruca, kpt. A. Bart. Zadanie tego zespołu to opracowanie koncepcji tras komunikacyjnych (parkingów, miejsc, zbiórek uczestników uroczystości, tras przemarszów), zabezpieczenie przejazdu związków taktycznych, organizacja i zabezpieczenie pilotażu na trasie przejazdu papieża.

4. Zespół ds. Współdziałania z Jednostkami i Instytucjami Pozaresortowymi: kierownik - ppłk M. Sarkowicz; członkowie - ppłk T. Boczar, ppłk F. Hain, ppłk R. Kaszycki, kpt. S. Duch, kpt. A. Gawroński, kpt. S. Dziedzic, por. W. Obrzut. Ten zespół, oprócz wielu innych zadań, miał się zająć współpracą i koordynacją działań z kościelną służbą porządkową, współdziałaniem ze służbą zdrowia, strażą pożarną i jednostkami gospodarki komunalnej w zakresie zabezpieczenia porządku i bezpieczeństwa publicznego.

5. Zespół Techniczno-Usługowy: kierownik - por. J. Cegliński; członkowie - kpt. U. Dobrakowska, mł. chor. A. Kłyk, sierż. Z. Ziaja, sierż. E. Bledzewska. Ich zadaniem było wykonywanie dokumentów graficznych do planów działania sił resortu spraw wewnętrznych, dokumentowanie pracy zespołu ochrony porządku publicznego oraz wykonywanie prac kancelaryjno-biurowych'.

Na podstawie decyzji nr 04/87 kierownika sztabu WUSW w Tarnowie z dnia 15 stycznia 1987 roku i decyzji kierownika Zespołu do Spraw Rozpoznania i Działań Operacyjno-Politycznych, a także w oparciu o wytyczne dyrektora Biura Śledczego MSW w sprawie zabezpieczenia wizyty papieża w Polsce, został powołany Podzespół ds. Dokumentacji Procesowo-Śledczej w składzie: kierownik podzespołu - ppłk J Bryk, naczelnik Wydziału Śledczego; zastępca kierownika podzespołu - ppłk R. Kaszycki, naczelnik Wydziału Dochodzeniowo-Śledczego; Członkowie podzespołu - mjr Fr. Duda zastępca Naczelnika Wydziału Dochodzeniowo-Śledczego; kpt. J. Dębski, starszy Inspektor Wydziału Śledczego; ppor. S. Wójcik, starszy inspektor Wydziału Śledczego.

Podzespół miał za zadanie przygotowanie i organizację osobowych i technicznych możliwości procesowo-śledczych, dokumentowanie ewentualnych zdarzeń, zachowań lub działań przestępczych. Miał też dokonać przeglądu aktualnie prowadzonych postępowań przygotowawczych pod kątem szybkiego ich zakończenia, dopilnowanie wspólnie z prokuratorami, sądami i kolegiami do spraw wykroczeń oraz zakładami karnymi realizacji decyzji centralnych, by w okresie od 1 do 15 czerwca 1987 roku wstrzymać wszelkie rozprawy sądowe, w których wykorzystywane byłyby konwoje MO, a także dopilnować, by nie wydano nikomu przepustek z zakładów karnych położonych na terenie województwa i ze Szpitala Psychiatrycznego z Dębicy.

\footnotetext{
${ }^{9}$ AIPN Kr 034/30, k.121-122, Decyzja nr 08/87 Szefa WUSW w Tarnowie z dnia 20 II $1987 r$
} 
W tym czasie miała zostać wstrzymana praca więźniów poza zakładami karnymi. Do zadań tego podzespołu należało także przygotować odpowiednią ilość miejsc w aresztach milicyjnych w następującej liczbie: w rejonie Tarnowa -42 miejsca, w rejonie Bochni - 68, w rejonie Brzeska - 14, Dębicy - 61, Dąbrowy Tarnowskiej - 24. Razem 209 miejsc. Członkowie tego podzespołu otrzymali także zadanie zabezpieczenia dla ewentualnych zatrzymań dodatkowych miejsc w zakładach karnych w Tarnowie i w Tarnowie-Mościcach oraz Dębicy. Należało także przygotować stałe i ruchome punkty zatrzymań osób popełniających przestępstwa i wykroczenia albo w inny sposób zagrażających bezpieczeństwu. Stałe punkty zatrzymań zostały umieszczone w Tarnowie w: RUSW Tarnów, WUSW Tarnów Świerczków przy ul. Zawadzkiego, KK MO Dworzec Kolejowy, Referat Dzielnicowy przy ul. Jasna. Ponadto w oparciu o przygotowane wcześniej listy, wydelegowani funkcjonariusze z Wydziału Śledczego i Dochodzeniowo-Śledczego przeprowadzili z osobami podejrzanymi rozmowy profilaktyczno-ostrzegawcze.

Niezależnie od przeprowadzonych wcześniej rozmów należało w oparciu o wcześniej przygotowane listy - dokonać zatrzymań prewencyjnych na 48 godzin wytypowanych wcześniej osób i umieścić je w zakładach leczniczych i innych ośrodkach izolacji, dokonać przeszukań i lustracji pomieszczeń, pojazdów itp. Nie zapomniano też o nawiązaniu bardzo ścisłej współpracy z Prokuraturą Wojewódzką i Rejonową w Tarnowie, a także z Wydziałem Administracyjnym Urzędu Wojewódzkiego w Tarnowie. Podzespół funkcjonował na bazie Wydziału Śledczego SB i DochodzeniowoŚledczego MO wsparty funkcjonariuszami Wydziału Techniki Kryminalistycznej oraz pracownikami delegowanymi z Wydziałów Śledczych innych województw. Podzespół dysponował 25 pracownikami dwóch wspomnianych wcześniej wydziałów, 3 samochodami osobowymi z radiotelefonami i 4 samochodami więźniarkami ${ }^{10}$.

\section{OPERACJA ,POSESJA”}

W związku z przyjazdem Jana Pawła II do Tarnowa na organach spraw wewnętrznych spoczął obowiązek zapewnienia bezpieczeństwa tak jemu, jak i towarzyszącym mu osobom. W związku z tym należało dokonać bardzo dokładnego rozpoznania wśród wszystkich mieszkańców tych budynków mieszkalnych i gospodarczych, w których mieściły się instytucje bądź przedsiębiorstwa usytuowane bezpośrednio przy trasach przejazdów i miejscach uroczystości, a także przy ulicach i placach przyległych. Rozpoznanie winno dotyczyć miejsca lądowiska i zarówno głównych, jak i zapasowych tras przejazdu i miejsc pobytu Ojca św. Dotyczyło to rejonu kurii diecezjalnej, Placu Katedralnego i Rynku oraz Osiedla Jasna II. Zadanie to wymagało właściwej organizacji, rzetelnego wykonania, perfekcyjnej dokumentacji

${ }^{10}$ AIPN Kr 034/30, k. 37-41, Plan działania Podzespołu ds. dokumentacji procesowośledczej. 
dokonanego rozpoznania. $\mathrm{W}$ tym celu należało przeprowadzić $\mathrm{w}$ Tarnowie akcję pod kryptonimem „Posesja”. Do jej zrealizowania zaproponowano zespół składający się z następujących funkcjonariuszy SB: kierownik - ppłk F. Hain, szef RUSW w Tarnowie; zastępca kierownika - kpt. T. Ożga, zastępca szefa RUSW w Tarnowie; członkowie zespołu - kpt. J. Kurtyka, starszy inspektor Wydziału Kryminalnego WUSW; ppor. M. Nowak, inspektor Wydziału Prewencji WUSW; ppor. Fr. Chrapusta, starszy inspektor Wydziału III.

Do przeprowadzenia operacji zaplanowano użyć głównie dzielnicowych, tworzac $\mathrm{z}$ nich podzespoły wspierane przez funkcjonariuszy $\mathrm{z}$ pionów: kryminalnego, kompanii patrolowej, jednostek MO będących w dyspozycji członków tworzących wspomniany zespół.

Do 16 marca 1987 roku miała zostać zorganizowana narada szkoleniowa ze wszystkimi funkcjonariuszami biorącymi udział w tej akcji. Postanowiono też zwiększyć liczbę funkcjonariuszy obsługujących telefon 997, pod którym zainteresowani mogliby zgłaszać uwagi i własne spostrzeżenia, do czego zostaną zobowiązani w czasie realizacji operacji „Posesja”.

Wspomniany zespół winien opracować plan i harmonogram operacji do 14 marca tr. i przedstawić go kierownikowi Zespołu Porządku Publicznego. W trakcie realizacji działań należało: przeprowadzić rozmowy z każdym właścicielem budynku znajdującego się wokół wskazanych wcześniej miejsc związanych z przejazdem lub pobytem papieża, zapytać o to, kto mieszka w tym lokalu, czy właściciele chcą udostępnić go osobie trzeciej, a jeśli tak, to komu, czy któraś z mieszkających tam osób nie cierpi na chorobę nerwową czy też psychiczna. Nie można było też pominąc przy realizacji tego typu zadania sprawdzenia, czy w danym lokalu nie mieszkają „osoby politycznie wrogie lub inne osoby mogące stanowić potencjalne zagrożenie bezpieczeństwa publicznego". Funkcjonariusze winni także zapytać, czy ktoś z mieszkających tam nie ma urządzeń nagłaśniających (kolumny, magnetofony, wzmacniacze), czy posiada zarejestrowany aparat telefoniczny, a jeśli tak, to jaki jest jego numer, czy posiada samochód, a jeśli tak, to gdzie go parkuje? Należało zatroszczyć się też o usunięcie rusztowań i urządzeń budowlanych, stert materiałów budowlanych i doprowadzić do estetycznego wyglądu terenu wokół remontowanych budynków. Terminem wykonania tych zadań upływał z dniem 30 maja 1987 roku. Przeprowadzający rozmowy z lokatorami mieli tych ostatnich ostrzec, by nie umieszczali w oknach i na ścianach swoich mieszkań dekoracji z „elementami o treści politycznej”. To tylko niektóre $\mathrm{z}$ całego szeregu zaleceń (maszynopis liczył 8 stron), jakie otrzymali mieszkający w domach położonych wokół trasy przejazdu Ojca Świętego. ${ }^{11}$

${ }^{11}$ AIPN Kr 034/30, k. 128-136, Decyzja nr 02/87 Kierownika Sztabu WUSW w Tarnowie z dnia 27 II 1987 r. w sprawie operacji „Posesja” w Tarnowie. 


\section{DALSZE PRZYGOTOWANIA}

SB starała się dobrze wywiązać z realizacji powierzonych zadań w związku z wizytą Jana Pawła II w Tarnowie. Wyrazem tego jest obszerny elaborat, liczący 6 stron maszynopisu, skierowany przez szefa WUSW w Tarnowie do naczelnika Wydziału IV, dowódcy ZOMO, szefa RUSW, w którym polecał „uaktywnić bezpośrednie rozpoznanie posesyjne, osobowe ze strony dzielnicowych i posterunkowych przez zacieśnienie kontaktów z mieszkańcami rejonów służbowych, z osobami ze szkół i zakładów pracy, poprzez zwrócenie szczególnej uwagi na osoby niezameldowane i tych, którzy zajmowali się drukiem i kolportażem wrogich ulotek albo działalnością konspiracyjną. Należało wzmóc infiltrację i dezintegrację środowisk przestępczych i milicyjnie podejrzanych, poznawać ich plany i przestępcze zamierzenia". Przewidywano włączenie specjalistycznych jednostek ORMO do działań i ochrony porządku publicznego na drogach, parkingach obszarach kolejowych, wykorzystanie ich do przeprowadzenia wzmożonych akcji porządkowych np. „Posesja” i „Spokój”. Do realizacji operacji „Zorza II” postanowiono włączyć członków straży przemysłowej, bankowej, SOK, straży pocztowej, straży leśnej. Przewidywano „objęcie wzmożoną kontrolą figurantów spraw operacyjnych", nakazano przeprowadzić rozmowy ostrzegawcze $\mathrm{z}$ niebezpiecznymi przestępcami zwolnionymi $\mathrm{z}$ więzień $\mathrm{w}$ latach 1985-1987. Należało też ukierunkować tajnych współpracowników „na uzyskanie wyprzedzających informacji operacyjnych o nieprawidłowościach i przestępstwach spekulacyjnych w handlu". Zwrócono szczególną uwagę na przeprowadzenie operacji o kryptonimie „Broń”, w czasie pracownicy SB mieli obowiązek sprawdzić legalność posiadania broni przez osoby fizyczne, którym takie pozwolenia ongiś wydano ${ }^{12}$.

Władze partyjno-państwowe obawiały się, że papieska wizyta może być w aktualnej sytuacji społecznej wykorzystana przez ,grupy antysocjalistyczne do działań godzących w podstawowe interesy PRL oraz storpedowania celów politycznych, jakie władze zakładają w związku z pobytem papieża". Obok możliwości zamachu na życie i zdrowie dostojnego gościa lub osób mu towarzyszących, obawiano się także, by „czasem nie doszło do wykorzystania imprez masowych $\mathrm{z}$ udziałem papieża do zamanifestowania działalności politycznej organizacji związanej z byłą Solidarnością". Nie chciano, by przedstawiciele opozycji zostali dopuszczeni do bezpośredniego otoczenia Papieża lub do niego osobiście ,między innymi w celu demonstrowania swojej obecności lub przekazywania negatywnych opinii o sytuacji w kraju", eksponowania transparentów, napisów z treściami antysocjalistycznymi, kolportażu ulotek. Postanowiono zatroszczyć się, by nie były widoczne ,grupy byłych internowanych osądzonych za działalność antypaństwową", by nie dopuścić do manifestowania obecności umundurowanych

${ }^{12}$ AIPN Kr 034/30, k. 195-198, Pismo Szefa WUSW Tarnowie do Naczelnika Wydziatu IV, Dowódcy ZOMO i Szefa RUSW w Tarnowie z dnia 31 III 1987 r. 
kombatantów AK ze sztandarami organizacji, zorganizowanych grup młodzieży, kombatantów, zakładów pracy „tendencyjnie oznakowanych”, służby liturgicznej, „młodzieży w strojach organizacyjnych ZHP z lilijkami, z podobizną głowy papieża". Chciano też przeciwstawić się z całą mocą udziałowi zorganizowanych grup rolników indywidualnych $\mathrm{z}$ terenu kraju z oznakowanymi transparentami, plakietkami, „które treściowo mają nawiązywać do byłej Solidarności R.I.” (Rolników Indywidualnych) ${ }^{13}$.

Nie zapomniano też o zakładach przemysłowych. Aby mieć całkowitą kontrolę nad zakładami, położonymi na terenie woj. tarnowskiego, w czasie wizyty papieskiej postanowiono przyjrzeć się obiektom chronionym przez straż przemysłową. Pod lupę wzięto następujące zakłady:

1. Zakłady Azotowe im. F. Dzierżyńskiego w Tarnowie.

2. Zakłady Mechaniczne „Tarnów” w Tarnowie.

3. Fabrykę Silników Elektrycznych „EMA-TAMEL” w Tarnowie.

4. Niedomickie Zakłady Celulozy w Niedomicach.

5. Dębickie Zakłady Opon Samochodowych „STOMIL” w Dębicy.

6. Wytwórnię Urządzeń Chłodniczych w Dębicy.

7. Dębicką Wytwórnię Farb i Lakierów „POLIFARB” w Dębicy.

8. Zakłady Tworzyw Sztucznych „ERG” w Pustkowie.

9. Zakłady Przetwórstwa Hutniczego HiL (Huta im. Lenina) w Bochni.

W ramach inspekcji postanowiono przeprowadzić ,,kontrolę fizycznego i technicznego zabezpieczenia obiektów, a w szczególności działów objętych ochroną tajemnicy państwowej i służbowej, środków masowego przekazu, punktów newralgicznych, pomieszczeń, w którym znajdują się urządzenia poligraficzne, radiowęzły oraz magazynów materiałów łatwopalnych, wybuchowych i toksycznych". W przypadku stwierdzenia nieprawidłowości dyrektorzy wymienionych zakładów zostali zobowiązani do niezwłocznego ich usunięcia. Zadania powinny były zostać wykonane do 25 maja 1987 roku. Należało też dokonać systematycznych kontroli wykonywania zadań przez straż przemysłową dotyczących ochrony obiektów. Postanowiono sprawdzić, czy dostatecznie zabezpieczono działy szczególnie strzeżone, a także nie dopuszczono do filmowania, fotografowania i szkicowania obiektów. Trzeba było zbadać, jak są przestrzegane przepisy przeciwpożarowe, oraz uczynić wszystko, by nie dopuścić do zakłócania porządku na terenie obiektów zakładowych w czasie wizyty papieża ${ }^{14}$.

Kierownictwo SB zdawało sobie sprawę $z$ tego, że do Tarnowa przybędą dyplomaci i cudzoziemcy i dlatego też 3 czerwca 1987 roku zastępca naczelnika Wydziału II WUSW w Tarnowie kpt. inż. Zbigniew Wilczyński zatwierdził ułożony przez starszego inspektora Wydziału II WUSW w Tarnowie mł. chor. Romana Węgla oraz inspektora Wydziału II WUSW w Tar-

\footnotetext{
${ }^{13}$ AIPN Kr 034/30, k. 110, Plan działań Nieetatowego...

${ }^{14}$ AIPN Kr 034/30, Harmonogram kontroli realizacji planów w zakresie zabezpieczenia fizycznego i technicznego obiektów chronionych przez uzbrojone formacje ochronne woj. tarnowskiego w ramach operacji krypt. ,Zorza II”, k. 35-36.
} 
nowie chor. Marka Wojtanowskiego: „Plan zabezpieczenia pobytu dyplomatów i innych cudzoziemców na terenie województwa tarnowskiego w okresie wizyty papieża Jana Pawła II w dnia 9 VI - 10 VI 1987 r.” Wydział II miał podjąć działania operacyjne w stosunku do dyplomatów, dziennikarzy, korespondentów i innych cudzoziemców, aby któryś z nich nie dopuścił się „prowokacji o charakterze terrorystycznym”. Zadania - o których poniżej winny być realizowane $\mathrm{w}$ okresie poprzedzającym wizytę, jak i w dniach wizyty Papieża, czyli od godziny 21.00 dnia 9 czerwca 1987 roku do godz. 17.00 dnia następnego, czyli do dnia wyjazdu Jana Pawła II z Tarnowa.

Zakładano, że do Tarnowa przybędzie około 700000 osób, a to pociągnie za sobą przyjazd korespondentów i dziennikarzy, których liczbę szacowano na około 1000. Rzeczą konieczną było „wykorzystanie całego stanu osobowego źródeł informacji oraz zintensyfikowanie współpracy z innymi wydziałami i jednostkami, by zapewnić sobie właściwy dopływ informacji”. Przewidywano, że dyplomaci - zwłaszcza z Francji, USA i Kanady - zamieszkają w Krakowie, a dziennikarze i korespondenci zachodni będa mieszkać w hotelu „Tarnovia”. Tam też planowano urządzenie centrum prasowego wyposażonego $\mathrm{w}$ odpowiednie środki łączności $\mathrm{z}$ dalekopisami włącznie. Przewidywano, że zamieszani w wywoływanie niepokoju w czasie wizyty papieskiej mogą wykorzystać przejeżdżające lub przyjeżdżające ciężarówki zwane TIR-ami do przewozu materiałów służących do „działań dywersyjno-terrorystycznych i nielegalnych wydawnictw".

Po skontaktowaniu się z funkcjonariuszami Wydziału V Biura Paszportów MSW w Warszawie stwierdzono, iż do Tarnowa wybierało się wielu Polaków zamieszkałych w krajach kapitalistycznych, ponieważ ubiegali się o wydanie im paszportów. Dotyczyło to zwłaszcza Polonii zamieszkałej w Austrii, Francji, RFN i USA. O paszporty w polskich ambasadach położonych w ww. krajach starali się także obywatele, którzy nie należeli do Polonii. Posiadano informacje, że teren województwa tarnowskiego zamieszkiwało 45 osób legitymujących się paszportem z krajów nie należących do krajów Demokracji Ludowej, a także 3 osoby z krajów arabskich. Co prawda, były to osoby starsze, ale jednak w myśl wytycznych Wydziału XIV Departamentu II MSW w Warszawie trzeba było zainteresować się nimi, zwłaszcza tymi, którzy pochodzili z krajów arabskich. Aby zatem nie doszło do ,podejmowania wrogich i negatywnych działań oraz stworzenia dogodnej możliwości penetracji naszego terenu i nawiązywania kontaktów przez zachodnie służby specjalne", postanowiono podjać stosowne działania. Należało do nich:

1) zapewnienie sobie informacji z Biura Ewidencji Ludności o meldunkach cudzoziemców z krajów kapitalistycznych przebywających czasowo na wspomnianym terenie $\mathrm{z}$ uwzględnieniem ich miejsc zamieszkania (w pobliżu tras i miejsc pobytu papieża), jak również charakteru i celu pobytu. To zadanie miał wykonać chor. Wojtanowski w dniach od 15 lutego do 10 czerwca 1987 roku; 
2) chorąży M. Wojtanowski i chorąży W. Cichocki otrzymali zadanie uzyskania informacji z Wydziału Paszportów dotyczących cudzoziemców, którzy starali się o przedłużenie wizy. Chodziło o rozpoznanie ich i stwierdzenie, ,czy nie pozostają w zainteresowaniu zarówno naszym, jak i innych jednostek w kraju np. podejrzanych o udział w międzynarodowych organizacjach terrorystycznych, powiązanych z obcymi służbami specjalnymi”;

3) uzgodnienie $z$ Wydziałem Prewencji zadań służących rozpoznaniu cudzoziemców, zamieszkałych $\mathrm{w}$ pobliżu planowanej trasy przejazdu papieża w czasie prowadzenia akcji „Posesja”, i zapoznanie się, czy nie podejmują oni „terrorystycznych działań, a także rozpoznanie miejsc dla zakonspirowania takich działań". Ponadto należało zwrócić się do Zwiadu Wojsk Ochrony Pogranicza o wcześniejsze informowanie o pobycie na omawianym terenie cudzoziemców i „konsularników” w okresie od 1 do 10 czerwca 1987 roku;

4) współdziałanie z Sekcją „B” WZO w miejscu i na bieżąco sprawdzanie jacy obcokrajowcy mieszkają w hotelach, zajazdach w województwie tarnowskim. Osoby takie należało rozpoznać i sprawdzić w ewidencji operacyjnej;

5) postanowiono dołożyć wszelkich starań, by przy pomocy tajnych współpracowników pozostających ,na kontakcie” pracowników Wydziału II dokonać właściwego zabezpieczenia „figurantów ewidencji operacyjnej” i zabezpieczyć miejsca ewentualnych postojów samochodów z rejestracją dyplomatyczną i TIR-ów. W przypadku uzyskania informacji mających wpływ na zagrożenie bezpieczeństwa Ojca św., należało je w trybie pilnym przekazywać do kierownika Wojewódzkiego Sztabu Operacji „ZORZA II”;

6) rzeczą konieczną było, by uzgodnić sposoby współdziałania z pracownikami Komedy Wojewódzkiej w Tarnowie „oraz podjęcie kroków zabezpieczających przed penetracją jednostek wojskowych przez przybyszów z krajów kapitalistycznych", a także zorganizowanie właściwego współdziałania z innymi jednostkami biorącymi udział w akcji „Zorza II”, a szczególnie z Wydziałem IV w „celu uzyskania bieżącego przepływu informacji oraz właściwego zabezpieczenia pobytu Jana Pawła II na naszym terenie" ${ }^{15}$.

Kierownictwo SB bardzo obawiało się rozruchów w czasie wizyty papieskiej. Sądzono, że istnieje możliwość aktów terrorystycznych ze strony osób podejrzanych. Dlatego Kierownik Zespołu Ochrony Porząaku Publicznego płk mgr E. Ceglarski skierował 28 maja 1987 roku specjalne pismo do naczelnika Wydziału IV WUSW w Tarnowie - w nawiązaniu do telekonferencji komendanta głównego gen. bryg. Z. Trzcińskiego z dnia 22 maja 1987 roku - i polecił podległym sobie funkcjonariuszom, by przygotowali wariant internowania osób podejrzanych o możliwość dokonania „,aktów terrorystycznych lub zakłócających porządek publiczny na okres pobytu papieża". Należało zatem zorganizować odpowiednie grupy operacyjno-dochodzeniowe w RUSW i w WUSW. Zadanie to polecono wykonać ppłk. J. Brykowi do

${ }^{15}$ AIPN Kr 034/30, k. 4-6, Plan zabezpieczenia pobytu dyplomatów i innych cudzoziemców na terenie województwa tarnowskiego $w$ okresie wizyty papieża Jana Pawła II w dniach 9 VI - 10 VI $1987 r$. 
dnia 2 czerwca 1987 roku, a ppłk. T. Boczarowi zlecono do dnia 8 czerwca 1987 roku dopracowanie szczegółów zabezpieczenia porządku publicznego i nakazano uwzględnić ,zagrożenia terrorystyczne ze strony obywateli polskich i państw obcych, możliwość podjęcia zorganizowanych, nielegalnych manifestacji, a także podjąć współdziałanie ze służbą kościelną”. Podpułkownik Z. Józefowicz został zobligowany, by poprzez podległych sobie funkcjonariuszy tak wpłynął na właścicieli sklepów położonych wokół trasy przejazdu papieża, aby zamknęli je na czas wizyty Ojca św., by została ograniczona do niezbędnego minimum liczba pracowników potrzebnych do utrzymania ciagłości pracy, a każdą z tych osób należało sprawdzić w kartotece. Osoby karane nie mogły wtedy wejść na teren zakładu pracy. Kapitan W. Cmunt do dnia 5 czerwca 1987 roku miał z pomocą swoich funkcjonariuszy przeprowadzić rozmowy ze wszystkimi posiadaczami broni palnej $\mathrm{w}$ celu prawidłowego jej zabezpieczenia, a w uzasadnionych przypadkach broń należało odebrać i na czas wizyty przechować w jednostce $\mathrm{MO}^{16}$.

Decyzja nr 035/87 szefa WUSW w Tarnowie z dnia 3 czerwca tr. wprowadzała stan podwyższonej gotowości bojowej garnizonu tarnowskiego od dnia 6 czerwca. Od 3 czerwca wstrzymano urlopy wypoczynkowe. W ramach podwyższonej gotowości bojowej wprowadzono 12-godzinny dzień pracy w systemie zmianowym, całodobowe dyżury kierowników MUSW i RUSW, całodobowe dyżury wzmocnionych grup operacyjno-dochodzeniowych w WUSW i w rejonowych urzędach spraw wewnętrznych na terenie całego województwa ${ }^{17}$.

\section{ROZMOWY ZE STRONĄ KOŚCIELNĄ}

23 lutego 1987 roku doszło do rozmowy kierownictwa WUSW w Tarnowie z przedstawicielami Kurii Diecezjalnej w Tarnowie. Spotkanie odbyło się w gabinecie płk. mgr. E. Kubraka, szefa WUSW w tym mieście. WUSW reprezentowali: szef WUSW i jego zastępca płk mgr J. Schiller. Ze strony kościelnej w spotkaniu wzięli udział bp Piotr Bednarczyk, tarnowski sufragan, i proboszcz parafii katedralnej w Tarnowie ks. prałat Kazimierz Kos. W czasie rozmowy dyskutowano nad szczegółami dotyczącymi uroczystości.

Zgodnie z przewidywanym planem Papież miał odprawić Mszę świętą na fundamentach nowo budowanego kościoła w dzielnicy Tarnowa popularnie zwanej „Falklandami”. Teren przed ołtarzem planowano podzielić na 11 sektorów promieniście rozchodzących się od ołtarza w kierunku zachodnio-północnym i północno-wschodnim. Sektory te miały być podzielone na 67 podsektorów, których wymiary należało dostosować do liczby zgromadzonych przy zastosowaniu skali - 3 osoby na $1 \mathrm{~m}$ kwadratowy. Przewidy-

${ }^{16}$ AIPN Kr 034/30, k. 150-152, Pismo Kierownika Zespolu Ochrony Porzqdku ptka mgra E. Ceglarskiego do Naczelnika Wydziału IV WUSW w Tarnowie z 28 V 1987 r.

${ }^{17}$ AIPN Kr 034/30, k. 155, Decyzja nr 035/87. 
wano przybycie około 1,3 mln wiernych. Sektor „,0" określono jako sektor „S”, był dostępny tylko dla zaproszonych gości i reprezentantów Kościoła ${ }^{18}$.

Przedstawiciele Służby Bezpieczeństwa przewidywali następującą frekwencję wiernych: w dniu przyjazdu około 150000 wiernych, w czasie uroczystości beatyfikacyjnych około $1,2 \mathrm{mln}$ wiernych, a na placu Katedralnym ok. 15 000. Szacowano, że z diecezji przemyskiej przybędzie do Tarnowa ok. 150 000, z diecezji krakowskiej ok. 500 000, katowickiej ok. 50 000, tarnowskiej ok. 600 000, kieleckiej - ok. 50 000. Ponadto planowany był udział zorganizowanych pielgrzymek z terenu kraju reprezentujących środowiska młodzieżowe, harcerskie, kombatanckie, rzemieślnicze, grupy folklorystyczne, a także środowiska polonijne ${ }^{19}$.

Przedstawiciele Kurii Diecezjalnej proponowali, by przed rozpoczęciem nabożeństwa pojazd papieski przejechał pomiędzy sektorami, ale nie wyrażono na to zgody $\mathrm{z}$ uwagi na fakt, iż uroczystości odbywać się będą w warunkach polowych, w miejscu, gdzie jest zaorane pole i w związku z tym samochód wiozący Ojca Świętego miałby kłopoty z przejazdem. Jednakże tak bp P. Bednarczyk, jak i ks. K. Kos nie chcieli zrezygnować z tego punktu, ponieważ - jak stwierdził tarnowski sufragan - ,gdybyśmy ograniczyli się tylko do nabożeństwa, to ludzie $\mathrm{z}$ dalszych sektorów, którzy po wielu trudach dotarli do Tarnowa, by go nawet nie zobaczyli". Ksiądz Kos dodał, że papież osobiście wyraził życzenie „by w czasie wizyty w Tarnowie nie oddalano go zbytnio od ludzi”. Ustalono, że ten punkt programu należy omówić jeszcze $\mathrm{z}$ czynnikami nadrzędnymi albo $\mathrm{w}$ ostatniej chwili papież podejmie $\mathrm{w}$ tej sprawie decyzję. W czasie owej rozmowy dyskutowano też o ustawieniu ołtarza papieskiego na fundamentach wspomnianego wcześniej kościoła.

Rozmawiano także o zabezpieczeniu miejsca spotkania Jana Pawła II na Placu Katedralnym z duchowieństwem tarnowskim. Przedstawiciele strony kościelnej podeszli ze zrozumieniem do postulatu wysuniętego przez kierownictwo WUSW, iż jest rzeczą konieczna, by funkcjonariusze SB dokładnie skontrolowali i zabezpieczyli wszystkie miejsca pobytu Jana Pawła II w Domu Biskupim, gdzie miał się zatrzymać i spędzić noc. W związku z tym, że papież pragnął spotkać się z wiernymi, zgromadzonymi przez budynkiem Kurii, przedstawiciele WUSW zaproponowali - oczywiście po uprzednim wyrażeniu zgody przez ordynariusza diecezji bp. J. Ablewicza by w oknie, w którym stanie papież, zamontowano szybę pancerną. Na zakończenie rozmowy bp P. Bednarczyk podziękował przedstawicielom WUSW w Tarnowie za życzliwe przyjęcie i pozostawił dwa numery telefonów, za pośrednictwem których istniała możliwość szybkiego z nim kontak-

${ }^{18}$ AIPN Kr 034/30, k. 168-171, Notatka stużbowa z rozmowy kierownictwa WUSW $w$ Tarnowie z przedstawicielami kurii diecezjalnej $w$ sprawie zabezpieczenia pobytu Jana Pawta II w Tarnowie z dnia 22 II 1987 r.

${ }^{19}$ AIPN Kr 034/30, k. 96-99, Plan operacyjno-fizycznego zabezpieczenia operacji kryptonim ,Zorza II” $w$ Tarnowie $w$ dniach 9 i 10 VI 1987 r. 
tu. On też powiedział, że bezzwłocznie przekaże bp. J. Ablewiczowi podjęte ustalenia, wnioski i uwagi ${ }^{20}$.

12 marca 1987 roku odbyło się kolejne posiedzenie Wojewódzkiego Sztabu Operacyjnego ds. Zabezpieczenia Wizyty Papieskiej w Tarnowie. $\mathrm{W}$ trakcie zebrania przyjęto następujące ustalenia i wnioski:

1. W terminie do 17 marca 1987 roku Kuria Diecezjalna w Tarnowie miała przedłożyć plan organizacji placu uroczystości głównych.

2. Wydział Zdrowia w porozumieniu ze stroną kościelną miał spowodować, by Zarząd Wojewódzki PCK wystapił pod wskazane przez stronę kościelną adresy zagraniczne o przesłanie leków, które miały zostać przekazane służbie zdrowia. Ponadto Wydział Zdrowia miał bezzwłocznie wystapić do Choragwi Tarnowskiej ZHP o zabezpieczenie 10 namiotów i 100 łóżek z materacami celem zorganizowania punktów pierwszej pomocy medycznej. Ponadto do końca marca tr. miano zadecydować, czy nie zajdzie potrzeba zaangażowania do niesienia pomocy medycznej potrzebującym sióstr zakonnych, które formalnie nie były podporządkowane służbie zdrowia. Postanowiono ponadto, by na czas wizyty papieża, czyli od wieczora 9 czerwca do godzin popołudniowych następnego dnia, nie zawieszać pracy w przychodni i stacji pogotowia ratunkowego przy ul. Dzierżyńskiego i uruchomić takie placówki w nowej przychodni przy ul. Skłodowskiej.

3. Ulica Graniczna na całej długości $(2100 \mathrm{~m})$ miała zostać gruntownie wyremontowana przez Rejon Budowy Dróg i Mostów w Bochni na polecenie Urzędu Wojewódzkiego, a Kuria Diecezjalna zobowiązała się, że zleci wykonanie remontu całej ul. Dąbrowskiej od ulicy Orkana do nowo budowanego kościoła $\mathrm{z}$ równoczesnym przygotowaniem dokumentacji projektowo-kosztorysowej i załatwieniem formalności związanych z prawem wejścia w teren. Prezydent miasta Tarnowa został zobligowany, by polecił RBDiM (Rejon Budowy Dróg i Mostów) wykonanie utwardzenia ul. Błonie, a Miejskie Przedsiębiorstwo Robót Drogowych na polecenie prezydenta miasta Tarnowa miało wykonać remont ul. Wojska Polskiego (do 31 maja 1987). Wykonanie i naprawę wszystkich dróg wewnętrznych na placu uroczystości wraz z dojazdami do ul. Granicznej zlecono stronie kościelnej, ona też miała zadbać o nagłośnienia placu uroczystości.

4. W terminie do 10 kwietnia tr. Kurię zobowiązano do podania orientacyjnej liczby wiernych, których należało przewieźć autobusami lub koleją. Strona kościelna miała też przez miejscowych proboszczów przeprowadzić rozmowy z właścicielami terenów pod parkingi i zyskać od nich pisemną zgodę na użyczenie tych terenów na czas trwania uroczystości. Również władze kościelne miały przygotować plakietki, z oznaczeniami na odwrocie rejonu parkowania, zezwalające na wjazd na owe parkingi. Powyższe ustale-

${ }^{20}$ AIPN Kr 034/30, k. 168-171, Notatka stużbowa z rozmowy kierownictwa WUSW $w$ Tarnowie z przedstawicielami kurii diecezjalnej $w$ sprawie zabezpieczenia pobytu Jana Pawła II w Tarnowie z dnia 22 II 1987 r. 
nia zostały zaakceptowane przez przedstawicieli władz miejskich i bp. P. Bednarczyka ${ }^{21}$.

23 marca 1987 roku w godzinach popołudniowych dokonano wizji lokalnej na placu uroczystości beatyfikacyjnych i w jej trakcie uzgodniono przebudowę planu ołtarza i sektorów - po kontakcie z funkcjonariuszami Biura Ochrony Rządu, WUSW i zespołami problemowymi ${ }^{22}$.

2 kwietnia 1987 roku odbyła się kolejna narada, w czasie której omawiano przebieg uroczystości w dniu 10 czerwca. Ustalono, że plac uroczystości centralnych obejmie obszar 76 ha i będzie podzielony na 57 pól sektorowych, w sektorze będzie przebywać po ok. 30000 osób i 20 porządkowych jednolicie oznakowanych (żółta furażerka i żółta opaska z papieskimi emblematami), właściciele gruntów wykorzystanych w czasie uroczystości pod parkingi, po spisaniu umowy z Kurią Diecezjalną, otrzymają stosowne odszkodowanie. Opracowano projekt wstępny ołtarza o następujących parametrach: miał być zbudowany na 6-metrowym podwyższeniu z wykorzystaniem fundamentów nowo budowanej świątyni, otrzyma dwa oddzielne wejścia i wyjścia, a głównym akcentem stanie się krzyż (wysokość $25 \mathrm{~m}$ ) $\mathrm{z}$ wolną przestrzenią o tym samym kształcie w jego wnętrzu. Przed ołtarzem zostanie wyeksponowany obraz bł. Karoliny Kózki.

Do projektu ołtarza i usytuowania sektorów wniósł uwagi przedstawiciel WUSW, stwierdzając, iż ołtarz winien być przebudowany $z$ uwagi na bezpieczeństwo papieża, za jego plecami nie może być bowiem otwarta przestrzeń, chyba że zostanie zapełniona szybą pancerna, przejazdy (te planowane) między sektorami są dość wąskie, a podział placu na sektory nie może być prostokątny, ale promienisty, natomiast przed ołtarzem powinien znajdować się plac na lądowisko dla helikoptera ${ }^{23}$.

W czasie spotkania strony kościelnej z przedstawicielami WUSW w dniu 22 kwietnia 1987 roku ustalono, że:

1. Zabezpieczenie wewnętrzne rezydencji (Dom Biskupi) przejmuje na siebie strona kościelna, co zostanie potwierdzone pisemnym oświadczeniem.

2. Zabezpieczenie zewnętrzne - wejścia, bramy - odbywać się będzie poprzez ustanowione mieszane służby kościelne i milicyjne.

3. Postanowiono, że strona kościelna wystąpi do ks. A. Orszulika o zainstalowanie osłony kuloodpornej we wcześniej wytypowanym oknie.

4. Strona kościelna przyjęła na siebie - i zostało to poświadczone odpowiednim pismem - ,zabezpieczenie dotyczące sprawdzeń sanitarnoepidemiologicznych i pirotechniczno-dozymetrycznych".

5. Wejście do rezydencji miało odbywać się na podstawie ustalonego systemu przepustowego obowiązującego w strefie „0”. Strona kościelna zobowiązała się do przekazania imiennej listy wszystkich osób mieszkających w Domu Biskupim oraz wykazu pojazdów samochodowych tam parkujących.

\footnotetext{
${ }^{21}$ AIPN Kr 034/30, k. 189-190, Informacja.

${ }^{22}$ AIPN Kr 034/30, k. 194, Informacja z dnia 2 IV 1987 r.

${ }^{23}$ AIPN Kr 034/30, k. 193, Informacja z dnia 2 IV 1987 r.
} 
6. Pozdrowienie dla Jana Pawła II miało być przekazane przez zorganizowane grupy pod oknem zwanym potem papieskim, ale pod opieką strony kościelnej.

Odnośnie zabezpieczenia placu uroczystości o kryptonimie „Jasna II”, obok wspomnianych wcześniej ustaleń, przedstawiciele Kurii zobowiązali się do wybrania szczególnie odpowiednich osób wyznaczonych do pełnienia służby porządkowej w strefie ,0" i strefie I, w rękawach wpustowych do strefy „0" i I, a także na trasie przejazdu Jana Pawła II. Osoby biorące udział w liturgii w strefie ,0", takie jak chór, orkiestra, koncelebransi, służba liturgiczna, osoby przyjmujące Komunię św. z rąk Ojca św. i niosące dary ofiarne miały zebrać się w punktach wyznaczonych przez stronę kościelną, skąd miały zostać przewiezieni na miejsce uroczystości. Po konsultacji z przedstawicielami Kościoła ustalono, że przepustki do strefy „," wykona BOR, a ich dystrybucja, po przedstawieniu list imiennych, zajmie się strona kościelna. Do przepustki strona kościelna dołącza bilet odpowiadający tej strefie. Przepustki do strefy I, odnośnie dystrybucji i produkcji, zostały powierzone WUSW w Tarnowie. Rozmawiano też w sprawie zabezpieczenia placu Katedralnego i Rynku w kierunku ul. Żydowskiej.

22 kwietnia 1987 roku dokonano na placu Katedralnym wizji lokalnej, a strona kościelna zobowiązała się do przygotowania mapy geodezyjnej z naniesieniem aktualnej sytuacji. Ona też miała wystapić do ks. A. Orszulika o zamontowanie szyby kuloodpornej w ołtarzu na placu Katedralnym, zobowiązała się zapewnić opiekę sanitarną w tym miejscu. Służby BOR wzięły na siebie dokonanie sprawdzenia pirotechniczno-dozymetrycznego katedry. Do tych ustaleń dodano, że „Obszar strefy I dzieli się na sektory o pojemności 4000 osób każdy i nadaje się im odrębne oznakowanie. Za produkcję przepustek (kart wstępu) do strefy I - po uzgodnieniu wzoru ze stroną kościelną odpowiedzialny był WUSW. Dystrybucją miała zając się strona kościelna, a nadzór ogólny nad całością miał sprawować WUSW w Tarnowie ${ }^{24}$.

Ustalono i dokładnie omówiono plan pobytu papieża Jana Pawła II w Tarnowie i przedstawiał się on następująco:

9 czerwca 1987 roku godz. 20.15 - przylot do Tarnowa. Lądowisko helikopterów wyznaczono w Tarnowie Zachodnim. Stąd miał nastapić przejazd do rezydencji biskupiej ulicami: Traugutta, Czerwonych Klonów, Czerwona, Krakowską i Dzierżyńskiego. Po przyjeździe do domu biskupa tarnowskiego SB nie przewidywała żadnych ,imprez o charakterze otwartym”.

10 czerwca 1987 roku

- godz. 8.15 - wyjazd z rezydencji biskupa tarnowskiego na miejsce uroczystości beatyfikacyjnych (czas przejazdu około 30 minut);

- godz. 9.00 - rozpoczęcie Mszy św. połączonej z beatyfikacją Karoliny Kózki;

${ }^{24}$ AIPN Kr 034/30, k. 202-205, Ustalenia $i$ wnioski podjęte na posiedzeniu strony kościelnej i WUSW odbytym w dniu 22 IV 1987 r. 
- godz. 11.45 - przejazd do rezydencji biskupa tarnowskiego po zakończeniu Mszy św. beatyfikacyjnej;

- godz. 14.30 - przejazd Ojca św. na plac Katedralny, gdzie spotka się duchowieństwem diecezjalnym oraz częścią porządkowej służby kościelnej;

- godz. 16.15 - zakończenie uroczystości na placu Katedralnym i odjazd do Tarnowa Zachodniego na lądowisko;

- godz. 16.45 - odlot do Krakowa.

\section{ZABEZPIECZENIA I KRYPTONIMY}

Zabezpieczenie przebiegu wizyty Jana Pawła II w Tarnowie zostało zaplanowane do realizacji w czasie następujących operacji, które osłaniali funkcjonariusze MO: „Lądowisko” (obejmowała zabezpieczenie przylotu papieża oraz trase przejazdu do domu biskupa tarnowskiego) - zabezpieczało ją 200 pracowników operacyjnych; „Lądowisko-Rezydencja” - 480 funkcjonariuszy; „Rezydencja” (obejmowała zabezpieczenie pobytu papieża w Kurii Diecezjalnej w Tarnowie oraz program ewentualnych zgromadzeń i spotkań papieża $\mathrm{z}$ wiernymi) - 50; „Rezydencja-Rzędzin II” - 350; ,Rzędzin II” (obejmowała zabezpieczenie uroczystości beatyfikacyjnej Karoliny Kózki w dniu 10 czerwca 1987 roku i trasy przejazdu Ojca Świętego Jana Pawła II z rezydencji bp. Ablewicza na miejsce uroczystości) - 540 funkcjonariuszy; „Rzędzin II-Rezydencja” - 350; „Rezydencja-Katedra” - 100; „Katedra” (zabezpieczenie spotkania papieża $\mathrm{z}$ duchowieństwem diecezji tarnowskiej w czasie nieszporów eucharystycznych na placu Katedralnym oraz na trasie przejazdu) 150; ,Katedra-Lądowisko” - 580; „Odlot” (obejmowała zabezpieczenie trasy przejazdu z placu Katedralnego do lądowiska) $-180^{25}$.

Ostatecznie jednak zwiększono liczbę funkcjonariuszy obsługujących realizację wspomnianych operacji. Operację „Lądowisko” zabezpieczało 650 pracowników operacyjnych w 13 grupach po 50 osób każda. Miejsce lądowania helikopterów zabezpieczała 1 grupa, a trasę przejazdu chroniło 12 grup, operację „Rzędzin II” zabezpieczało 600 pracowników w 12 grupach po 50 osób każda (trasy przejazdu z Kurii Diecezjalnej w Tarnowie strzegło 8 grup, a bezpieczeństwa w sektorach pilnowało 200 funkcjonariuszy (4 grupy po 50 osób), operację „Katedra” zabezpieczało 400 pracowników (na trasie przejazdu rozstawiono 100 , czyli 2 grupy po 50 funkcjonariuszy), a na placu Katedralnym znalazło się 300 milicjantów, czyli 6 grup po 50 osób każda) ${ }^{26}$.

Został także utworzony Nieetatowy Pododdział Operacyjno-Interwencyjny (NPOI) liczący 30 pracowników operacyjnych, którego dowódcą został mianowany por. J. Biernat. Miał on przydzielone następujące zadania:

${ }^{25}$ AIPN Kr 034/30, k. 110-111, Plan działań Nieetatowego Pododdziału OperacyjnoInterwencyjnego powołanego decyzja Kierownika Zespołu Rozpoznania i Działań Operacyjno-Politycznych $w$ zwiazku $z$ wizytq $w$ Tarnowie papieża Jana Pawła II.

${ }^{26}$ AIPN Kr 034/30, k. 198, Załacznik do zestawienia sit i środków do zabezpieczenia operacji kryptonim ,ZORZA II" z 31 III 1987 r. 
„eliminowanie poprzez zatrzymanie, znakowanie inspiratorów i organizatorów zagrożeń i osób agresywnie zachowujących się w thumie, prowadzenie rozpoznania $\mathrm{w}$ rejonach zagrożenia poszczególnych operacji, rozwijanie w miejscach zagrożenia działań, które by neutralizowały, dezintegrowały i dezorganizowały tłum, przeszukiwanie miejsc i obiektów zagrożonych, a także mieszkań osób, które były podejrzane przez MO, dokumentowanie przebiegu działań i zabezpieczenie dowodów z miejsca wydarzeń" 27.

Zgodnie z decyzją kierownika Sztabu Operacji „Zorza II” do dyspozycji WUSW w Tarnowie zostali przydzieleni funkcjonariusze MO z: WUSW Krosno - 230 funkcjonariuszy, WUSW Nowy Sącz - 230, WUSW BielskoBiała - 230, WUSW Przemyśl - 250, WUSW Rzeszów - 350. Milicjanci z Krosna zostali zakwaterowani w Internacie Szkół Chemicznych przy ul. Szarych Szeregów i otrzymali zadanie zabezpieczenia realizacji operacji „Lądowisko” i częściowo operacji „Katedra”. Część z nich została przydzielona do NPOI. Łącznikiem tej grupy funkcjonariuszy ze Sztabem Głównym mianowano kpt. E. Żelazo. Milicjanci z WUSW z Nowego Sącza zostali zakwaterowani w internacie Technikum Ogrodniczego przy ul. Ziai. Zabezpieczali operacje „Lądowisko-Rezydencja” w dniu 9 czerwca i „Rzędzin” w dniu 10 czerwca. Łącznikiem został kpt. B. Łokieć. Funkcjonariuszy z Bielska-Białej umieszczono w liczbie $180 \mathrm{w}$ internacie przy ul. Szarych Szeregów, a pozostałych $\mathrm{w}$ internacie przy ul. Ziai. Im zlecono 9 czerwca realizację operacji „Blokada”, a 10 czerwca operacji „Katedra-Lądowisko” i „Rezydencja-Katedra”. Na łącznika wyznaczono kpt. W. Pragłowskiego. Zakwaterowani w internacie Szkoły Chemicznej przy ul. Czerwonych Klonów funkcjonariusze z Przemyśla całością sił zabezpieczali 9 czerwca realizację operacji „Lądowisko-Rezydencja” i 10 czerwca operację „Rzędzin II”. Rolę łącznika wziął na siebie por. T. Komuniecki. Milicjanci z WUSW Rzeszów zostali zakwaterowani w Szkole Podstawowej nr 8 przy ul. Bitwy pod Studziankami i całością sił pilnowali przebiegu operacji „RezydencjaRzędzin II” i „Rzędzin II-Rezydencja” oraz „Katedra-Lądowisko” w dniu 10 czerwca. Łącznikiem tej grupy został kpt. J. Pęcherek.

Do realizacji operacji „Rezydencja” w dniach 9 i 10 czerwca oddelegowano 49 funkcjonariuszy z Bochni, Dąbrowy Tarnowskiej i z Tarnowa, a także kilkunastu pracowników z Wydziału Paszportów i z Wydziału Kryminalnego. Do dyspozycji Biura Ochrony Rządu oddelegowano 30 funkcjonariuszy, natomiast po uzgodnieniu z BOR-em do realizacji zadań Wydziału IV w bezpośrednim otoczeniu papieża zostali delegowani: kpt. J. Brzuszek, por. R. Konarski i ppor. M. Nazaruk. 1 czerwca 1987 roku Wydział IV WUSW w Tarnowie zorganizował naradę dowódców sił przydzielonych do dyspozycji Sztabu WUSW w Tarnowie. W trakcie narady starano się omówić wykorzystanie sił poszczególnych jednostek, podział zadań w odniesie-

${ }^{27}$ AIPN Kr 034/30, k. 110-111, Plan działań Nieetatowego Pododdzialu OperacyjnoInterwencyjnego powołanego decyzja Kierownika Zespołu Rozpoznania i Działań Operacyjno-Politycznych $w$ zwiazku $z$ wizyta w Tarnowie papieża Jana Pawła II. 
niu do określonych operacji, a także bieżąca sytuację operacyjną związaną z wizytą Jana Pawła II w tym mieście. Ustalono, iż przydzielone siły operacyjne przybędą do Tarnowa 8 czerwca na godz. 12.00. Czas od przybycia do rozpoczęcia służby $\mathrm{w}$ określonych operacjach mieli wykorzystać na zapoznanie się z wzorami przepustek do poszczególnych stref, kontaktami ze służbą mundurową i służbą kościelną, a także na uczestnictwo w szkoleniu $\mathrm{z}$ zachowania się $\mathrm{w}$ określonych sytuacjach ${ }^{28}$.

\section{WNIOSEK O ZAKOŃCZENIE SPRAWY OBIEKTOWEJ}

10 czerwca 1987 roku zakończyła się wizyta Jana Pawła II w Tarnowie. 24 września 1987 roku płk J. Schiller podpisał przygotowany przez naczelnika Wydziału IV WUSW w Tarnowie wniosek o zakończeniu sprawy obiektowej o kryptonimie „Pielgrzym”. Sprawa ta była prowadzona „na imprezy związane z wizytą Jana Pawła II w Tarnowie". W ramach tej akcji „realizowano zadania operacyjne ukierunkowane na zabezpieczenie wizyty Jana Pawła II w Tarnowie w oparciu o szczegółowo opracowane plany działań operacyjno-politycznych obejmujące zarówno działania poprzedzające wizytę, jak i te w czasie jej trwania i na zakończenie". Uroczystości związane z wizytą Papieża zawierały:

1. Powitanie papieża na lądowisku oraz jego przejazd do rezydencji w dniu 9 czerwca 1987 roku (w dokumentacji mylnie napisano „86 r.”).

2. Uroczystości główne, w czasie których papież wygłosił homilię i dokonał beatyfikacji Karoliny Kózki oraz mianował do godności arcybiskupa bp. Jerzego Ablewicza.

3. Nieszpory eucharystyczne na Placu Katedralnym, w trakcie których Papież wygłosił homilię do duchowieństwa diecezji tarnowskiej.

4. Przejazd Papieża z rezydencji na lądowisko, gdzie nastąpiło jego pożegnanie. Całość „imprez” związanych z wizytą Jana Pawła II w Tarnowie została zabezpieczona operacyjnie, technicznie i fotograficznie. $Z$ uwagi na to, że wizyta Papieża w Tarnowie zakończyła się 10 czerwca 1987 roku, materiały sprawy obiektowej „Pielgrzym” nr rejestracyjny TA-9284 złożono w Sekcji „C” WZO WSW w Tarnowie ${ }^{29}$.

${ }^{28}$ AIPN Kr 034/30, k. 99-103, Plan operacyjno-fizycznego zabezpieczenia operacji kryptonim ,,ZORZA II" w Tarnowie $w$ dniach 9 i 10.06.1987 r.

${ }^{29}$ AIPN Kr 034/30, k. 26-27, Wniosek o zakończeniu sprawy obiektowej. W artykule pojawiły się następujące skróty: AIPN Kr - Archiwum Instytutu Pamięci Narodowej w Krakowie; BOR - Biuro Ochrony Rządu; GMT - Gospodarka Materiałowo-Techniczna; KK MO - Komisariat Kolejowy Milicji Obywatelskiej; MO - Milicja Obywatelska; MUSW - Miejski Urząd Spraw Wewnętrznych; NPOI - Nieetatowy Pododdział Operacyjno-Interwencyjny; ORMO - Ochotnicze Rezerwy Milicji Obywatelskiej; RUSW - Rejonowy Urząd Spraw Wewnętrznych; SB - Służba Bezpieczeństwa; WOP - Wojska Ochrony Pogranicza; WUSW - Wojewódzki Urząd Spraw Wewnętrznych; WZO - Wydział Zabezpieczenia Operacyjnego; ZOMO - Zmechanizowane Odwody Milicji Obywatelskiej. 


\section{PREPARING FOR THE VISIT OF POPE JOHN PAUL II IN TARNÓW HELD FROM JUNE 9-10, 1987 IN LIGHT OF THE CASE FILE OBJECT "PILGRIM"}

\section{Summary}

On the route of the third pilgrimage of Pope John Paul II to Poland, which took place from June 8 to 14, 1987 was Tarnów. Holy Father Pope John Paul II arrived to Tarnow in the late evening of June 9 and left in the afternoon of the next day. During this time, he met with the large number of faithful people who came from across the South-East of Poland and beyond. During Mass on June 10 he celebrated to the glory of the altars Karolina Kózka who was murdered by a Russian soldier on November 18, 1914. He also met with the clergy in the Cathedral Square in Tarnów. Activities that were related to the protection of Pope John Paul II during his visit in Tarnów were given the codename „Aurora II”. During Popes visit In Tarnow there were appointed head of security staff and several operational teams. Tarnow SB officers were supported by the officers from neighboring provinces. The documents related to this task were in the briefcase 8 I 1987, code-named object file „Pilgrim”.

(ttumaczyła mgr Ilona Bibrowicz)

Keywords:

Security Service, Pope John Paul II, Archbishop Jerzy Ablewicz, the Cathedral Square, Tarnów 